\title{
A Simple Method for Operating the Delta Connection Standard of the 3-phase Induction Motor on Single Phase Supply
}

\author{
Zuriman Anthony \\ Department of Electrical Engineering, Padang Institute of Technology (Institut Teknologi Padang) \\ JL. Gajah Mada Kandis Nanggalo Padang, West Sumatra, Indonesia
}

\begin{abstract}
This research is purposed to establish a simple method for operating the three phase induction motors of delta connection standard with single-phase power by using capacitor circuit to the motor. The research was conducted at the Laboratory of the Electrical Engineering of Institut Teknologi Padang. The object used in this research was the 3-phase induction motor of $1.5 \mathrm{HP}, 380 / 220 \mathrm{~V}, \mathrm{Y} / \Delta, 2.75 / 4.74 \mathrm{~A}, 4$ poles, 50 Hz, 1400 RPM. The results showed that the motor could work well on single phase power load by up to $66 \%$ of the 3-phase rating. The motor could operated on power factor close to unity, with lower current harmonic distortion and efficiency $99.76 \%$.
\end{abstract}

Keywords: Capacitor circuit, capacitance of the start and run capacitors, current flowing to the winding of the motor.

\section{INTRODUCTION}

The 3-phase induction motor is an electric motor which is widely used today, especially in the industrialized world since the motor is widely available with great power. This motor operates normally using the 3-phase power system. This motor has 3 coils identities are separated from each other across $120^{\circ}$ electricity that powered by a 3phase power system. They will produce a resultant magnetic flux that rotates like poles actual magnet spinning mechanism. In certain areas which are only available 1-phase power system, it is not possible to operate the motors on normal operation. Therefore, the motors are forced to operate on a 1phase system.

In general, the 3-phase induction motor has two types connection coil for operating in normal operation, namely wye and delta connection system as shown in Fig. 1. To improve the starting torque and operating characteristics of the motors, they could be operated on a single phase supply as shown in Fig. 2 and Fig.3.

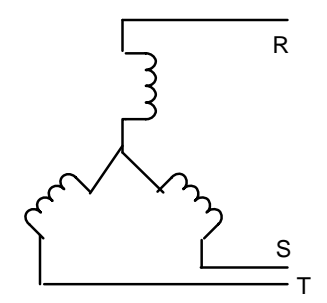

a) Wye connection

$\begin{array}{cc}\text { a) Wye connection } & \text { b) delta connetion } \\ \text { Fig. } 1 \text { Two types connection coil of the 3-phase induction motor for operating }\end{array}$ on 3-phase power system

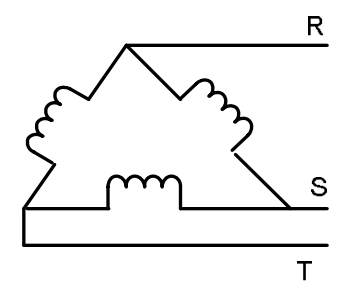

b) delta connetion
-phase induction motor for operating

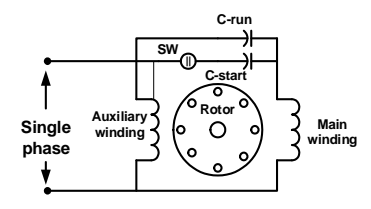

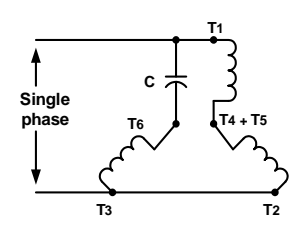

b)

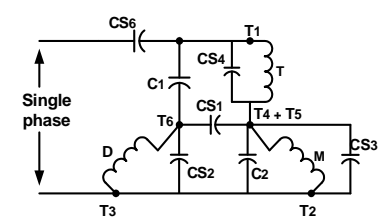

c)
Fig. 2 Induction motors operation on single phase supply: a) single phase capacitor motor: b) 3-phase induction motor according to Scheda ${ }^{9}:$ c) 3-phase induction motor according to Smith ${ }^{10}$.

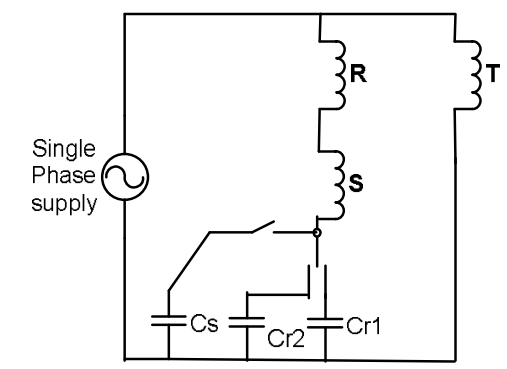

Fig. 3 The method for operating the 3-phase induction motors on single-phase supply (for Wye connection standard) ${ }^{7}$

Figs. 2 and 3 show some methods for operating the induction motors on single phase power. Fig. 4 shows a method that used for operating the delta 
connection standard of the 3-phase induction motor on a single phase supply. Fig. 5 shows the control circuit used in the Fig. 4 for operating the motor on single phase supply.

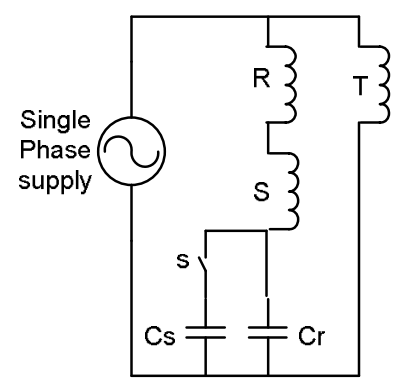

Fig. 4 The method for operating the delta connection standard of the 3-phase induction motors on single-phase supply

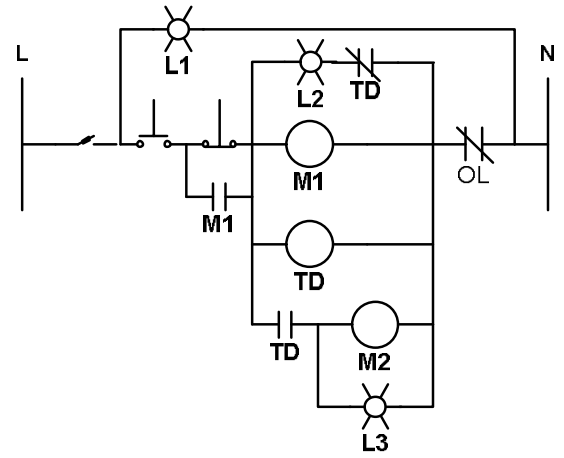

Fig. 5 Control circuit used in Fig. 4

\section{START CAPACITOR}

Referring to Fig. 4 can be explained that the start capacitor ' $\mathrm{Cs}$ ' and run capacitor ' $\mathrm{Cr}$ ' accidentally placed in series with the coil $\mathrm{R}$ and $\mathrm{S}$ are to create the highest torque of the motor. If referring to the theory of the 'Torque start maximum per ampere', the formula, then can be obtained as follow ${ }^{5,7}$ :

$$
X_{C(P U)}=X a+\frac{-X m R a+|Z m| \sqrt{R a(R a+R m)}}{R m}
$$

' $\mathrm{X}_{\mathrm{C}(\mathrm{PU})}$ ' is the capacitive reactance of the start capacitor to be used (in Per-unit system, $\mathrm{Pu}$ ), ' $\mathrm{Xa}$ ' is the inductive reactance of the coil $\mathrm{R}$ and $\mathrm{S}$ (in $\mathrm{Pu}$ ), $\mathrm{Ra}$ is the resistance of the coil $\mathrm{R}$ and $\mathrm{S}$ (in $\mathrm{Pu}$ ), ' $\mathrm{Xm}$ ' is the inductive reactance of the coil $\mathrm{T}$ (in $\mathrm{Pu}$ ), ' $\mathrm{Rm}$ ' is the resistance of the coil $\mathrm{T}$ (in $\mathrm{Pu}$ ) and ' $\mathrm{Zm}$ ' is the impedance of the coil $\mathrm{T}$ (in $\mathrm{Pu}$ ). To obtain the true value of ' $\mathrm{Xc}$ ', it must be sought from the base impedance values used in induction motor by using the following formula ${ }^{3}$.

$$
Z b=\frac{V^{2}}{V A}
$$

' $\mathrm{V}$ ' is a single phase voltage source $\left(\mathrm{V}_{\mathrm{LN}}\right)$, 'VA' is apparent power of the 3-phase induction motor and ' $\mathrm{Zb}$ ' is the base impedance of the motor. Furthermore, we will obtain the actual value of the capacitive reactance ' $\mathrm{X}_{\mathrm{C}}$ ' for the delta connection standard of the motor must be becomes ${ }^{5,7}$.

$$
X_{C}=\left(X_{C(p u)}\right) \cdot(Z b)
$$

The value of the capacitance of start capacitor 'Cs' than can be obtained for delta connection standard of the motor by using the following equation.

$$
C s=\frac{1}{\sqrt{3} \cdot\left(2 \cdot \pi \cdot f \cdot X_{C}\right)}(\text { Farad })
$$

The equation (4) then can be rewritten as follows:

$$
C s_{\Delta}=\frac{(0,11033) \cdot\left(I_{L}\right)}{(f) \cdot\left(V_{L N}\right)}(\text { Farad })
$$

' $\mathrm{Cs}_{\Delta}$ ' is the total capacitance of the start capacitor $\left(\mathrm{Cs}+\mathrm{Cr}\right.$ from fig. 4), ' $\mathrm{I}_{\mathrm{L}}$ ' is the line current standard of the motor (A), ' $\mathrm{f}$ ' is the source frequency $(\mathrm{Hz}), \mathrm{V}_{\mathrm{LN}}$ is the amplitude of the single phase voltage source of line to neutral (Volt).

\section{RUN CAPACITORS}

Refer to Fig. 4, for best performance of the motor, the run capacitor ' $\mathrm{Cr}$ ' must be at setting as follows.

$$
C r_{\Delta}=0,0693 x \frac{\left(I_{p h}\right)}{(f)\left(V_{L N}\right)}
$$

' $\mathrm{Cr}_{\Delta}$ ' is the total capacitance of the run capacitor 'Cr' from fig. 4. By using both equations (5) and (6) the motor can operate well up to $66 \%$ of its 3 phase load rating in power factor close to unity.

The voltage on the capacitor ' $\mathrm{V}_{\mathrm{C}}$ ' on Fig. 4 is becomes 2 times of the source voltage ' $\mathrm{V}_{\mathrm{LN}}$ ', then can be made as follows ${ }^{5,7}$ :

$$
\mathrm{V}_{\mathrm{C}}=2 . \mathrm{V}_{\mathrm{LN}}
$$

The amount of reactive power $\left(\mathrm{VAR}_{\mathrm{C}}\right)$ which donated the capacitor then can be written from equation (7) as ${ }^{5,7}$ : 


$$
V A R_{C}=\omega \cdot C \cdot\left(V_{C}\right)^{2}=4 \cdot \omega \cdot C \cdot\left(V_{L N}\right)^{2}
$$

$\mathrm{C}$ is referred to $\mathrm{Cr}_{\Delta}$ from the Fig. 4. $\mathrm{VAR}_{\mathrm{C}}$ will become apparent power of the 3-phase induction motor when operate on 1-phase power. If $\mathrm{VAR}_{3 \mathrm{ph}}$ is a reactive power while the motor operates at 3phase supply, the amount of reactive power induction motor in a single phase supply $\left(\mathrm{VAR}_{\mathrm{M}}\right)$ becomes $^{5,7,11}$ :

$$
\mathrm{VAR}_{\mathrm{M}}=\mathrm{VAR}_{3 \mathrm{ph}}-\mathrm{VAR}_{\mathrm{C}}
$$

The magnitude of the line current $\left(\mathrm{I}_{\mathrm{L}-1}\right)$, power factor $(\cos \phi)$ and input power $\left(\mathrm{P}_{\mathrm{L}}\right)$ of the motor in a single phase supply become $\mathrm{e}^{5,7,11}$ :

$$
\begin{aligned}
& I_{L_{-} 1}=\frac{V A R_{C}}{V_{L N}} \\
& \sin \phi=\frac{V A R_{M}}{V A R_{C}} \\
& \cos \phi=\cos \left(\sin ^{-1} \phi\right) \\
& P_{L}=V A R_{C} \cdot \cos \phi
\end{aligned}
$$

\section{TEST RESULT}

The motor used in this research is the 3-phase induction motor of $1.5 \mathrm{HP}, 380 / 220 \mathrm{~V}, \mathrm{Y} / \Delta$, 2.75/4.74 A, 4 poles, $50 \mathrm{~Hz}, 1400 \mathrm{RPM}$. The motor is operated in delta connection standard on 3-phase supply (from Fig.1b) and by using fig. 4 on single phase supply. Test result of this research about power factor, rotor speed of the motor, efficiency, and total current harmonic distortion are given in Figs $6,7,8$ and 9 respectively. The control box of the motor with all components that used in this research is given in Fig. 10.

The red lines in the Fig. 6 until Fig. 9 are the characteristics of the motor during operation on 3phase system, while the black lines are during operation on a single phase system using a run capacitor $30 \mu \mathrm{F}$. From the figures can be seen that in general the motor can operate with better performance on single phase power compared to operating on three-phase power, but the output power of the motor (66\% from the 3-phase rating). From the data in Fig. 6 until Fig. 9 show that with the same load conditions the motor can operate on single phase supply with higher power factor (close to unity), higher efficiency $(99,759 \%)$ and lower harmonic distortion.

From the result of this research can be seen that the motor has better performance while operating on single phase supply.

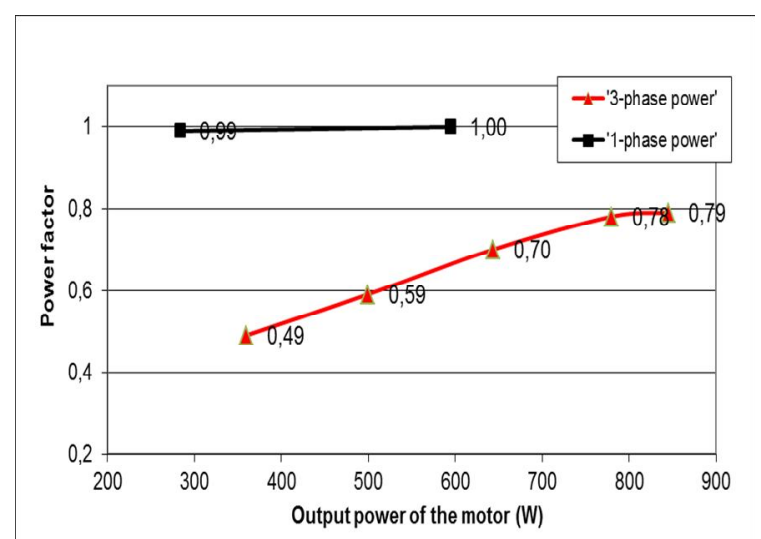

Fig. 6 Power factor characteristic when operating on a 3-phase and a 1-phase power

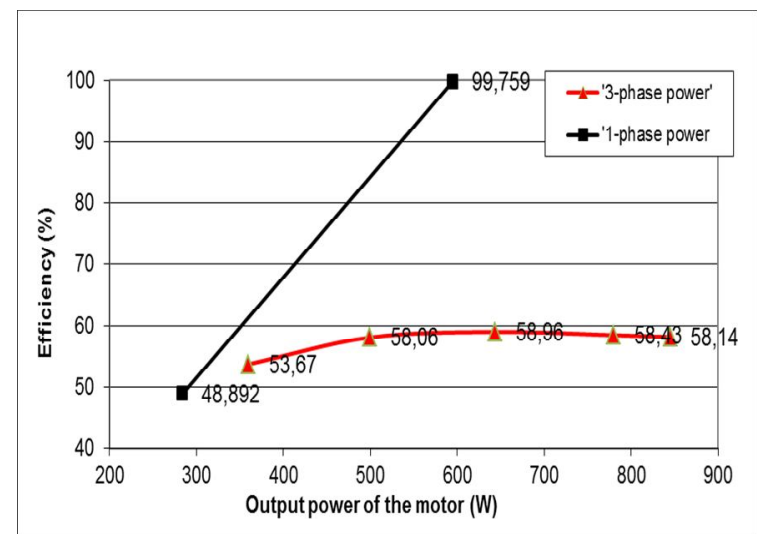

Fig. 8 Efficiency characteristic of the 3-phase induction motor when operating on a 3-phase and a 1-phase power

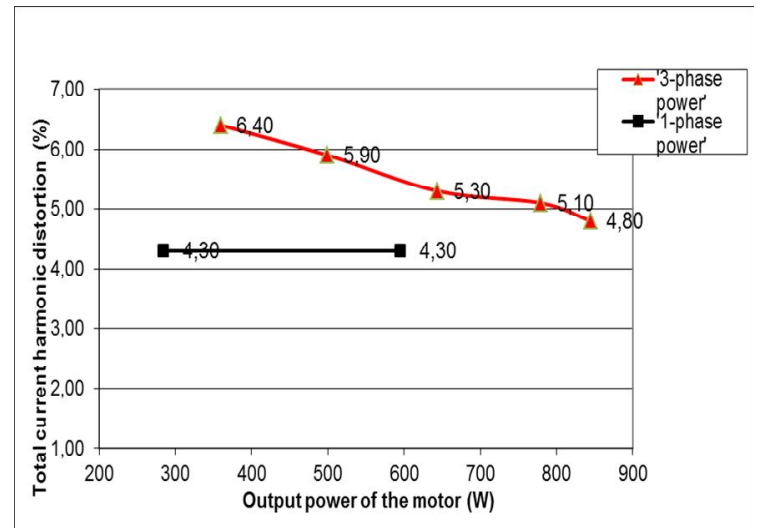

Fig. 9 Total Harmonic Distortion characteristic of the 3-phase induction motor when operating on a 3-phase and a 1-phase power 


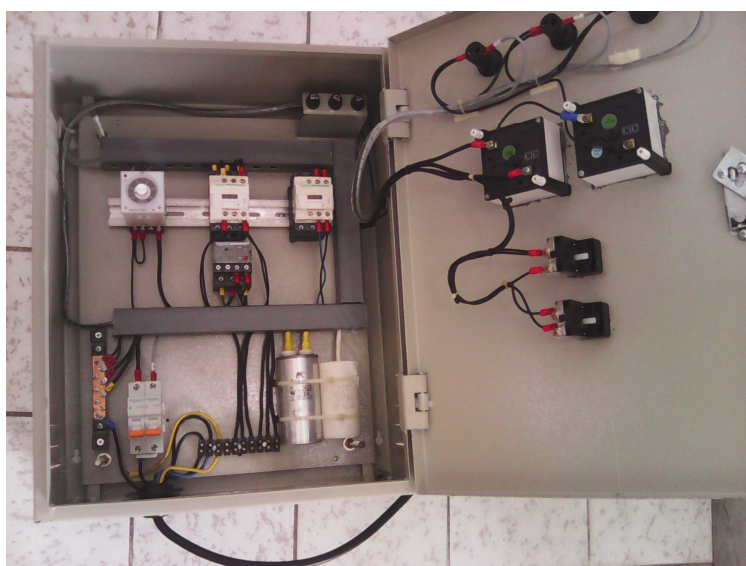

Fig. 10 The control box of the delta connection standard the 3-phase induction motor for operating on single-phase power

\section{CONCLUSIONS}

From the research that has been done can be summarized as follows.

1. The method that used in this research could work well to operate the delta connection standard of the 3-phase induction motor on single-phase power at load up to $66 \%$ of its 3 -phase nominal rating.

2. The method can operate the motor at a power factor close to unity, higher efficiency $(99,759 \%)$ and lower harmonic distortion

\section{ACKNOWLEDGMENT}

I extend a thank you to the team at the laboratory of electrical engineering of the 'Institut Teknologi Padang' who have helped this research run smoothly. I would also like to thank for the 'Kopertis Wilayah X' of Indonesia that has funded this research.

\section{REFERENCES}

[1] Anthony, Z, Tumiran, and Berahim, H, "The performance of the 3 phase induction motor while operating on single phase supply (Kinerja pengoperasian motor induksi 3-fasa pada sistem tenaga 1-fasa dengan menggunakan kapasitor)", Journal of Teknosain UGM , vol. 16 no. 1, pp. 1-12, Jan. 2003.

[2] Anthony, Z, 2004, "Analysis of the run capacitor circuit of the Semihex ${ }^{\mathrm{TM}}$ motor's method (Analisa kapasitor jalan pada metode Semihex ${ }^{T M}$ motor), in Proc. SNVMS 2004 Conference, 2004, pp. 637641.

[3] Anthony, Z, "The design of the start capacitor circuit to operate the 3phase induction motors on single phase power (Perencanaan kapasitor start untuk mengoperasikan motor induksi 3-fase pada sistem tenaga 1fase)", Journal of Momentum ITP, vol. 2 no. 2, pp. 9-13, Aug. 2004

[4] Anthony Z, "The Dual function control system design for operating the 3-phase induction motor (Perancangan sistem kendali dual fungsi pengoperasian motor induksi 3-fasa)", Journal of Momentum ITP, vol. 3 no. 2, pp. 58-63, Aug. 2005.

[5] Anthony, Z, "The design of the capacitor run circuit to operate the 3phase induction motors on single phase power (Perancangan kapasitor jalan untuk pengoperasian motor induksi 3-fasa pada sistem tenaga 1fasa)", Journal of Teknik Elektro UK Petra, vol. 8 no. 1, pp. 46-51, March 2008

[6] Anthony, Z, "Capacitor bank Effect to the starting current of the 3phase induction motor (Pengaruh penggunaan kapasitor perbaikan faktor daya terhadap arus start motor induksi 3-fasa), Journal of Teknik Elektro ITP, vol. 2 no. 1, pp. 26 - 32, Jan. 2013.

[7] Anthony, Z, "A simple method for operating the three-phase induction motor on single phase supply (for wye connection standard)" International Journal of Engineering Trends and Technology (IJETT), vol. 5 no. 1, Nov. 2013, pp. 13 - 16 .

[8] Badr M.A, Alolah A.I and Halim Abdul M.A, "A capacitor start three phase induction motor", IEEE transaction on energy conversion, vol. 10 no. 4, pp. 675-680, Dec. 1995.

[9] Huang H, Fuchs EF and White J.C, "Optimal placement of the run capacitor in single phase induction motor designs", IEEE transactions on energy conversion, Vol. 3, no. 3, pp. 647-652, Sep. 1988.

[10] Scheda, F. A, Operating 3-phase motors on 1-phase power, EC\&M, January 1985, pp. 40-41.

[11] Smith, O.J, "Large Low-Cost Single-phase Semihex ${ }^{\mathrm{TM}}$ Motor “, IEEE Trans. on Energy Conversion, vol. 14 no. 4, pp. 1353-1358, 1999,.

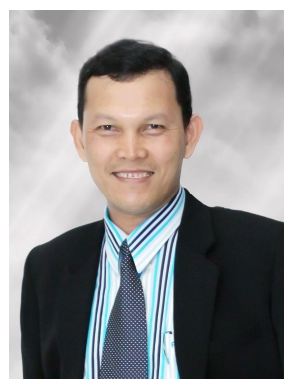

Zuriman Anthony is a lecturer in the 'Institut Teknolgi Padang' (Padang Institute of Technology) on Department of Electrical Engineering. His research's interest in Electrical Machines and control. $\mathrm{He}$ received an M.Eng from Gadjah Mada University, Yogyakarta, Indonesia in 2002. He always active in many researches about the three phase induction motors. 